\title{
Bilateral ape hand deformity
}

Figure Severe cervical cord compression leading to an ape hand deformity
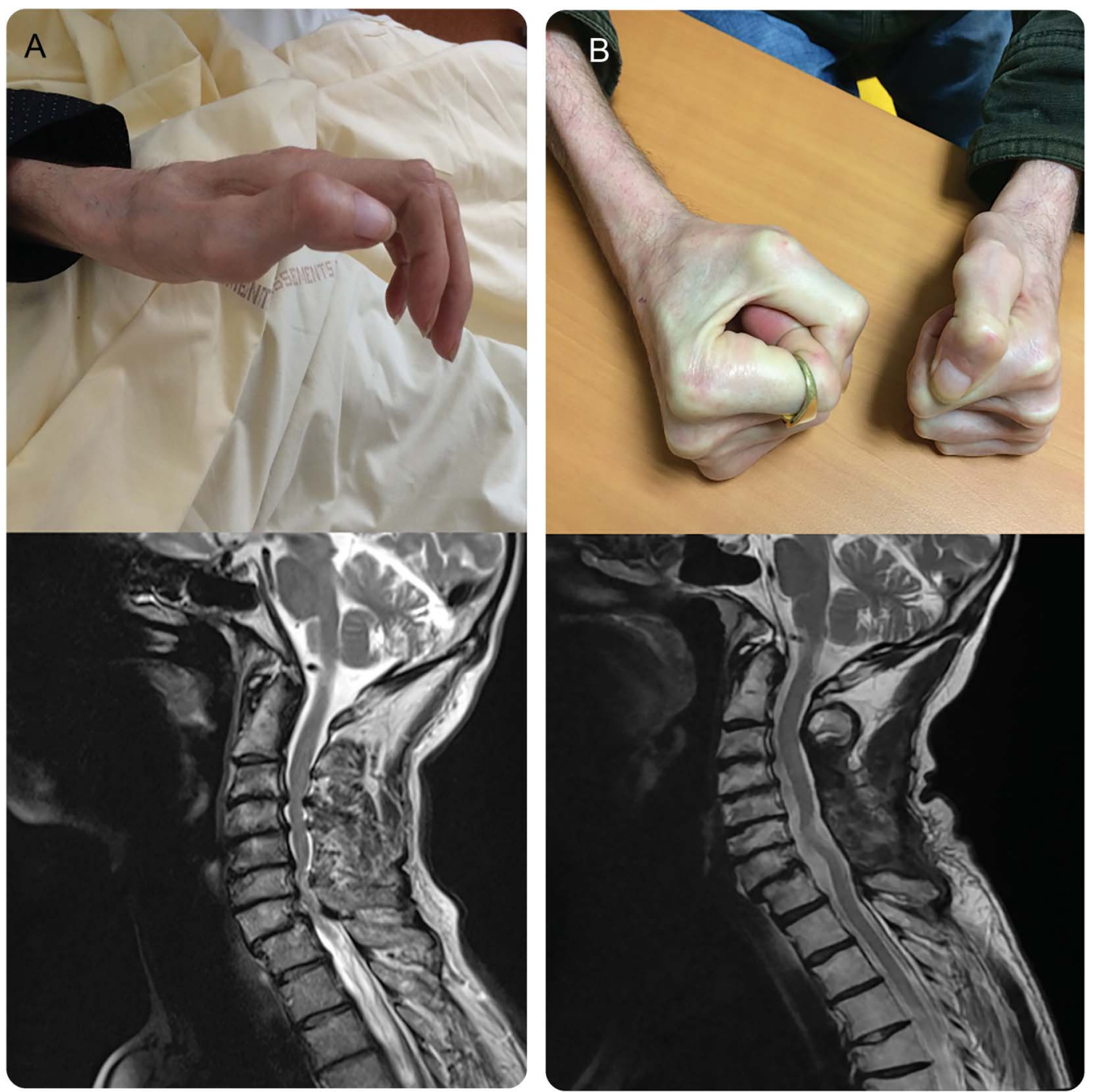

(A) Symmetric severe thenar and palmar interossei amyotrophy, weakness in forearm pronation, and wrist and finger flexion. Spinal cord MRI shows severe cervical anterior and posterior cord compression. (B) Improvement of ape hand deformity after spine cord decompression, as demonstrated by cervical MRI.

A 54-year-old man with a history of alcohol abuse ( $>2$ bottles of wine per day for 40 years) presented with 2 years of progressive weakness in all 4 limbs. Alcoholic polyneuropathy was diagnosed on clinical grounds and gabapentin was used for alcohol withdrawal. ${ }^{1}$

Typical ape hand syndrome was found (figure, A) with a pyramidal syndrome, which led us to question the previously established diagnosis of alcohol polyneuropathy. Spinal cord MRI showed severe cervical cord compression. 
A cervical posterior decompression was performed that relieved the patient's symptoms (figure, B), and the ape hand deformity improved after physiotherapy, followed by recovery of both ambulation and prehension, but alcohol consumption continued.

Aymeric Amelot, MD, PhD, François Lechanoine, MD, Patrick François, MD, PhD, Louis-Marie Terrier, MD From Bretonneau University Hospital (A.A., F.L., P.F., L.-M.T.), Tours; and La Pitié-Salpêtrière University Hospital (A.A.), Paris, France.

Author contributions: A.A., L.-M.T.: design or conceptualization of the study. L.-M.T., F.L., P.F., A.A.: analysis and interpretation of the data. A.A., L.-M.T., F.L., P.F.: drafting or revising the manuscript for intellectual content.

Study funding: No targeted funding reported.

Disclosure: The authors report no disclosures relevant to the manuscript. Go to Neurology.org for full disclosures.

Correspondence to Dr. Amelot: aymmed@hotmail.fr

1. Zeng L, Alongkronrusmee D, van Rijn RM. An integrated perspective on diabetic, alcoholic, and drug-induced neuropathy, etiology, and treatment in the US. J Pain Res 2017;10:219-228.

\section{WriteClick ${ }^{\circledR}$ rapid online correspondence}

Have a comment on a recent $N e u r o l o g y{ }^{\circledR}$ article you would like to share? Now it is easier and more convenient. Neurology.org has launched WriteClick on the home page and sidebars of each article to encourage remarks and debate among users.

WriteClick is restricted to comments about studies published in Neurology within the last eight weeks.

Learn more at Neurology.org/letters

\section{Visit the Neurology ${ }^{\circledR}$ Resident \& Fellow Website}

Click on Residents \& Fellows tab at Neurology.org.

Now offering:

- Neurology ${ }^{\circledR}$ Resident \& Fellow Editorial team information

- "Search by subcategory" option

- E-pearl of the Week

- RSS Feeds

- Direct links to Continuum ${ }^{\circledR}$, Career Planning, and AAN Resident \& Fellow pages

- Recently published Resident \& Fellow articles

- Podcast descriptions

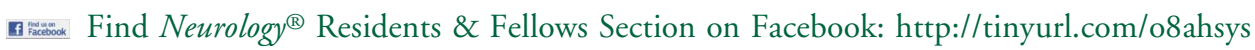

twitter Follow Neurology ${ }^{\circledR}$ on Twitter: http://twitter.com/GreenJournal 


\title{
Neurology
}

\author{
Bilateral ape hand deformity \\ Aymeric Amelot, François Lechanoine, Patrick François, et al. \\ Neurology 2017;89;638-639 \\ DOI 10.1212/WNL.0000000000004219
}

This information is current as of August 7, 2017

$\begin{array}{ll}\begin{array}{l}\text { Updated Information \& } \\ \text { Services }\end{array} & \begin{array}{l}\text { including high resolution figures, can be found at: } \\ \text { http://n.neurology.org/content/89/6/638.full }\end{array} \\ \text { References } & \text { This article cites } 1 \text { articles, } 0 \text { of which you can access for free at: } \\ & \text { http://n.neurology.org/content/89/6/638.full\#ref-list-1 } \\ \text { Subspecialty Collections } & \text { This article, along with others on similar topics, appears in the } \\ & \text { following collection(s): } \\ & \text { All Spinal Cord } \\ \text { http://n.neurology.org/cgi/collection/all_spinal_cord } & \text { Clinical neurology examination } \\ & \text { http://n.neurology.org/cgi/collection/clinical_neurology_examination } \\ & \text { Peripheral neuropathy } \\ & \text { http://n.neurology.org/cgi/collection/peripheral_neuropathy } \\ & \text { Information about reproducing this article in parts (figures,tables) or in } \\ & \text { its entirety can be found online at: } \\ \text { http://www.neurology.org/about/about_the_journal\#permissions } & \text { Information about ordering reprints can be found online: } \\ \text { Permissions \& Licensing } & \text { http://n.neurology.org/subscribers/advertise }\end{array}$

Neurology ${ }^{\circledR}$ is the official journal of the American Academy of Neurology. Published continuously since 1951, it is now a weekly with 48 issues per year. Copyright @ 2017 American Academy of Neurology. All rights reserved. Print ISSN: 0028-3878. Online ISSN: 1526-632X.

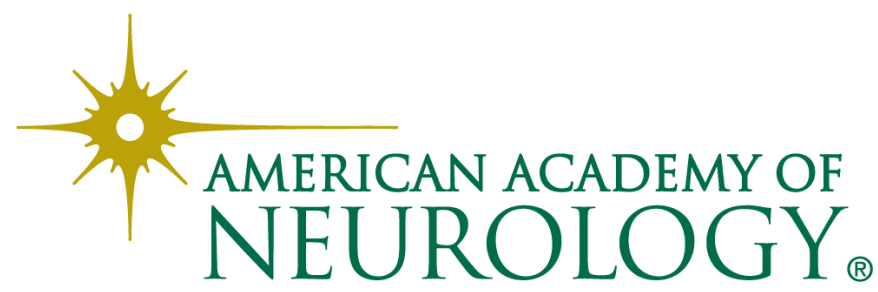

